\title{
Per se Performance and Heterosis in Relation to Gene Action for Seed Yield and Yield Related Traits in Chickpea
}

\begin{abstract}
Background: The productivity of chickpea needs to be increased significantly to exploit the maximum benefit from the increasing world market demand for this crop. Hence, the objective of this study was to find suitable heterotic cross combinations for yield and yield related traits in chickpea.

Methods: The present study on chickpea was conducted at Norman E. Borlaug Crop Research Centre, GBPUAT, Pantnagar, Uttarakhand, during rabi season of 2018-2019. It comprised a half-diallel set of seven diverse parents viz. PG5 and PG170 and five ICRISAT chickpea collections viz. ICC13124, ICC14778, ICC14815, ICC16348 and ICC16349 and their $21 \mathrm{~F}_{1}$ crosses were used for heterosis studies through $7 \times 7$ diallel analysis with respect to seed yield and other yield contributing traits.

Result: Variance components of combining ability revealed that both additive and non-additive gene actions were important for yield and yield related traits. The parent ICC13124 was best general combiner for yield and related traits. It was also one of the parents in best specific combinations for seed yield. The crosses viz. PG170×ICC16349 (7.15), ICC13124×ICC14815 (3.22) and ICC $13124 \times$ ICC14778 (3.00) were the best specific cross combinations for seed yield. The highest heterosis for seed yield was observed in cross PG170×ICC16349 (73.14\%) followed by ICC13124×ICC14815 (43.17\%) and ICC13124×ICC14778 (41.09\%). The results showed direct association between the specific combining abilities of the crosses and heterotic response indicating the involvement of additive $\times$ additive type of interactions causing heterosis. Hence, the GCA, SCA and per se performance of the crosses should be given equal importance while selecting for heterotic combinations.
\end{abstract}

Key words: Chickpea, Combining ability, Diallel, Gene action, Heterosis, Yield.

\section{INTRODUCTION}

Chickpea (Cicer arietinum L.) is a cool season seed legume with high nutritive value and is the third most important pulse crop in the world after dry bean and dry pea. It has $2 n=2 x=16$ chromosomes with relatively small genome size of 738.09 Mbp (Varshney et al. 2013). It is native to South Europe and is the most important pulse crop of India, commonly grown in Uttar Pradesh, Panjab, Maharashtra, Rajasthan, Bihar and Madhya Pradesh accounting for more than $90 \%$ of the total area under it. India is the largest producer of chickpea, accounting for $65 \%$ of the total world production (FAO, 2019). In addition to being a major source of dietary protein for humans in semiarid tropical regions, chickpea plays an important role in the maintenance of soil fertility, particularly in dry areas.

Although it has paramount importance in our daily diet yet its production does not meet the demand of the population. The reason of its low production is the precarious weather conditions which pose abiotic and biotic stresses on chickpea crop. One of the effective and practical methods to cope with these stresses is to create genetic variability for identification of germplasm possessing tolerance/ resistance against these stresses. In this context exploitation of hybrid vigour for tolerance/ adaptation could play a pivotal role. The productivity of chickpea in India is low and instable, which may be attributed to the evolution of cultivars with narrow genetic base making them vulnerable to various environmental stresses. Cultivar with narrow genetic base emerged due to the extensive use of few and closely related
Department of Genetics and Plant Breeding, College of Agriculture, Govind Ballabh Pant University of Agriculture and Technology, Pantnagar-263 153, Uttarakhand, India.

Corresponding Author: Priyanka Halladakeri, Department of Genetics and Plant Breeding, Anand Agricultural University, Anand388 110, Gujarat, India. Email: priyankahalladakeri6798@gmail.com

How to cite this article: Halladakeri, P., Arora, A., Panwar, R.K. and Verma, S.K. (2022). Per se Performance and Heterosis in Relation to Gene Action for Seed Yield and Yield Related Traits in Chickpea. Legume Research. DOI: 10.18805/LR-4623.

Submitted: 30-03-2021 Accepted: 15-01-2022 Online: 02-03-2022

germplasm lines in crop improvement program (Malik et al. 2010).

Breeders have been utilizing the available genetic resources to modify the varieties to meet the ever changing requirements. In this regard the most important development in plant breeding of recent times is the extensive use of heterosis (Malik et al. 2010). In practical heterosis breeding, it is imperative to select the cross combinations with high degree of specific combining ability (SCA) as well as parents with high general combing ability (GCA). Hence it is necessary to evaluate the combining ability, which is useful to assess the nicking ability of parents, at the same time elucidates the nature and magnitude of different types of gene action involved. The magnitude of heterosis particularly for yield is of paramount importance and if the heterosis is 
of high magnitude, it can help to achieve high productivity and thereby high yield levels. Therefore, in view of these facts and considering the importance of chickpea, the present study was conducted to study the nature and magnitude of heterosis in chickpea in relation to general and specific combining abilities for seed yield and its components.

\section{MATERIALS AND METHODS \\ Experimental location}

The experiment was conducted at Norman E. Borlaug Crop Research Centre, GBPUAT, Pantnagar, U.S Nagar, Uttarakhand, Situated at an altitude of $243.84 \mathrm{~m}$ above the mean sea level, Pantnagar lies between $29^{\circ} \mathrm{N}$ latitude and $79.3^{\circ} \mathrm{E}$ longitude.

\section{Plant materials}

The experimental material comprised of $21 \mathrm{~F}_{1}$ 's (excluding reciprocals) generated by involving 7 diverse parents in a $7 \times 7$ half diallel cross set. The genotypes involved in study included five ICRISAT chickpea collections viz. ICC13124, ICC14778, ICC14815, ICC16348 and ICC16349 and two varieties released from Pantnagar viz. PG5 and PG170. All the seven parents were sown in the crop season 2017-18 and crossed in a half diallel fashion.

\section{Experimental design and treatments details}

The resulting $21 \mathrm{~F}_{1}$ 's hybrids and parents were evaluated in a randomized block design with two replications in the rabi season (December to April) 2018-19. All the agronomic practices were followed to raise a normal and healthy crop.

\section{Data observation}

Observations were recorded on five competitive plants from seven parental genotypes and their $F_{1}$ 's in each replication. The observations were recorded on days to $50 \%$ flowering, days to maturity, plant height $(\mathrm{cm})$, number of primary branches per plant, number of secondary branches per plant, pods per plant, seeds per pod, seed yield per plant (g), 100 seed weight $(\mathrm{g})$, biological yield $(\mathrm{g})$ and harvest index $(\%)$.

\section{Statistical analysis}

The data were subjected to statistical analysis as per the method given by Panse and Sukhatme (1969) and difference in magnitude of average heterosis and heterobeltiosis were computed for various characters as per the formula given by Hayes et al. (1995) and Fonseca and Paterson (1968).

$$
\begin{array}{r}
\text { Relative heterosis }(\mathrm{MPH})=\frac{\left(\overline{\mathrm{F}}_{1}-\overline{\mathrm{MP}}\right)}{\overline{\mathrm{MP}}} \times 100 \\
\text { Heterobeltiosis }(\mathrm{BPH})=\frac{\left(\overline{\mathrm{F}}_{1}-\overline{\mathrm{BP}}\right)}{\overline{\mathrm{BP}}} \times 100
\end{array}
$$

Where,

$\mathrm{F}_{1}=$ mean performance of $\mathrm{F}_{1} ; \mathrm{BP}=$ mean of the better parent; $\mathrm{MP}=$ mean of two parents.

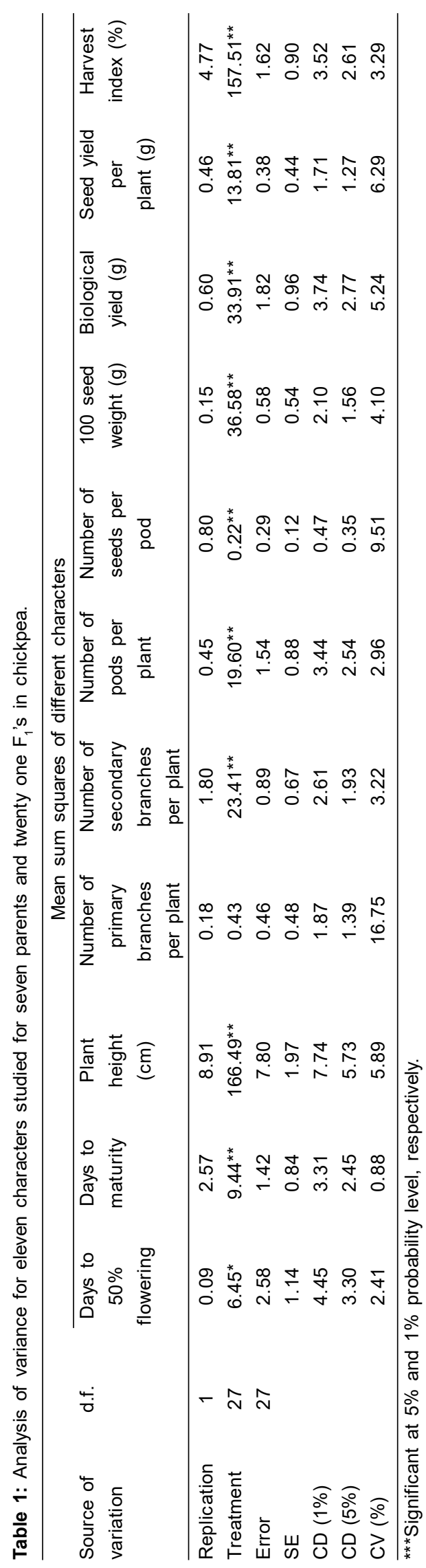




\section{RESULTS AND DISCUSSION}

The analysis of variance for all the eleven characters were carried out before proceeding for detailed statistical analysis and the results were presented in Table 1. It was cleared from the table that genotypes differ significantly for all character except number of primary branches per plant. This indicated the presence of inherent differences among the genotypes. Hence, it was proved that suitable experimental materials were chosen for present investigation. The analysis of variance for combining ability showed that both additive and non additive gene action were important for controlling the expression of traits under investigation.

The aim of estimating heterotic effects in present study is to find out the best combinations of parents giving high degree of heterobeltiosis and its exploitation to get better transgressive segregants and characterization of parents for their prospects for future use in chickpea breeding. The magnitude of heterosis, measured as per cent increase or decrease of $F_{1}$ value over mind parent (MPH) and better parent (heterobeltiosis) for all the characters under study are presented in Table 2 .
Overall results on heterosis on eleven yield contributing traits showed that, none of the cross exhibited heterosis for all the traits. Based on per se performance and SCA, the superior crosses were ICC $14815 \times I C C 16348$ and ICC $14815 \times$ ICC 16349 for days to $50 \%$ flowering, while PG5 $\times$ ICC 16348 for days to maturity based on SCA and heterosis, for number of secondary branches per plant the superior crosses were PG5×ICC14778 and ICC13124 $\times I C C 14778$ based on per se and SCA. Based on SCA and heterosis, top crosses were PG5×PG170 and ICC13124 $\times$ ICC16348 for number of pods per plant, while ICC 14778 $\times$ ICC16348 for number of seeds per pod, ICC13124 $\times$ ICC14815 for 100 seed weight, ICC $13124 \times$ ICC 16348 for biological yield. However, ICC $13124 \times$ ICC 14815 and ICC13124 $\times$ ICC 16348 were superior for seed yield per plant based on per se performance and heterosis; while ICC13124 $\times$ ICC 14815 based on per se and SCA. For harvest index the promising crosses were PG5×PG170, ICC13124 $\times$ ICC 14778, ICC $14778 \times$ ICC 16348 based on SCA and heterosis. The cross PG170 1 ICC16349 was heterotic for seed yield per plant and 100 seed weight. Its heterotic performance was corresponded with its high SCA in 100

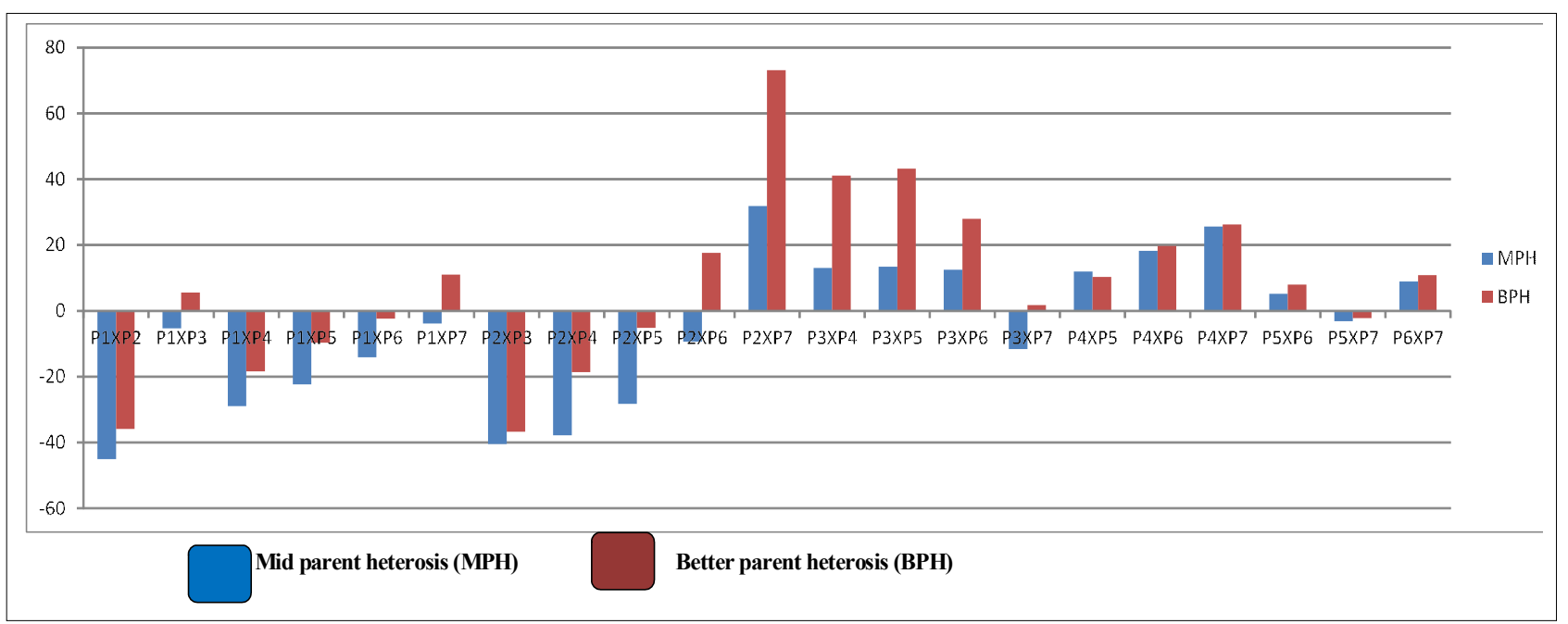

Fig 1: Better parent and mid parent heterosis for seed yield per plant.

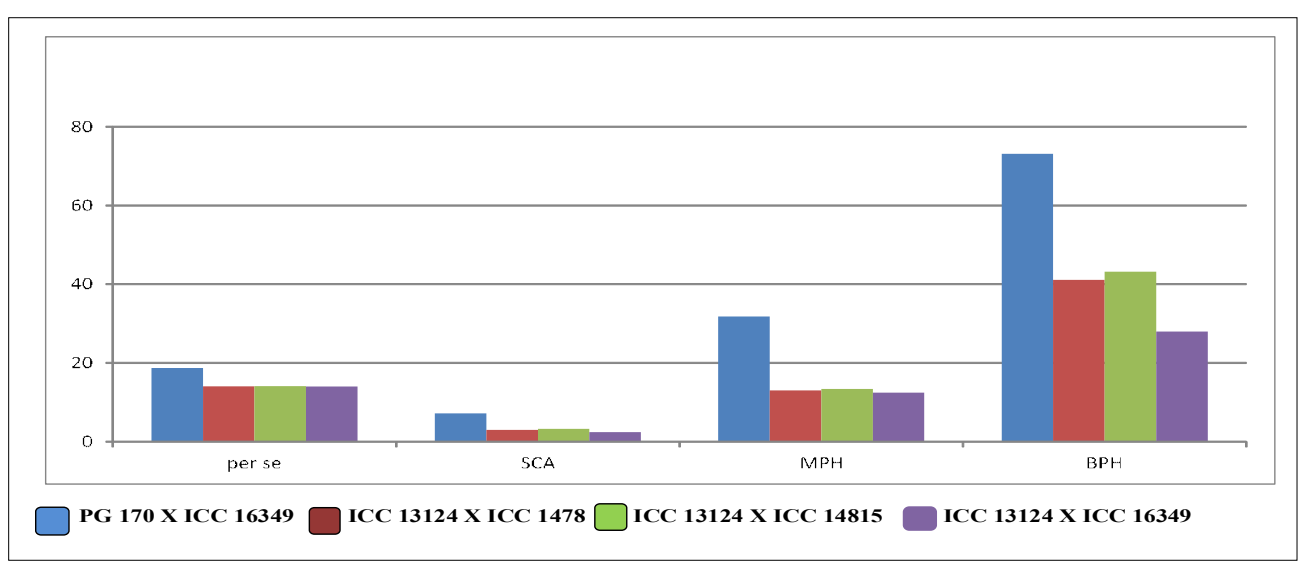

Fig 2: Top Four promising crosses on the basis of per se performance for seed yield per plant (g). 


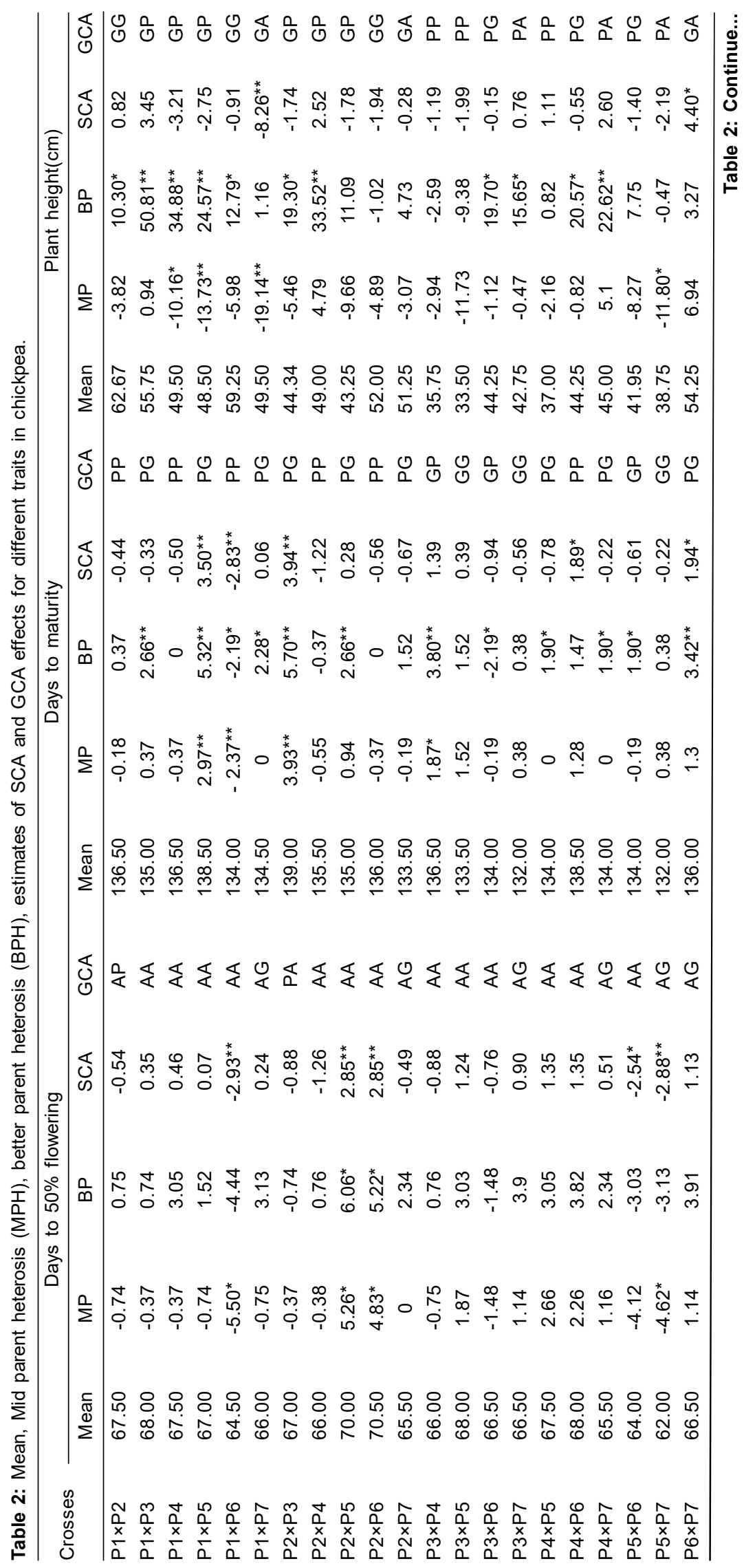




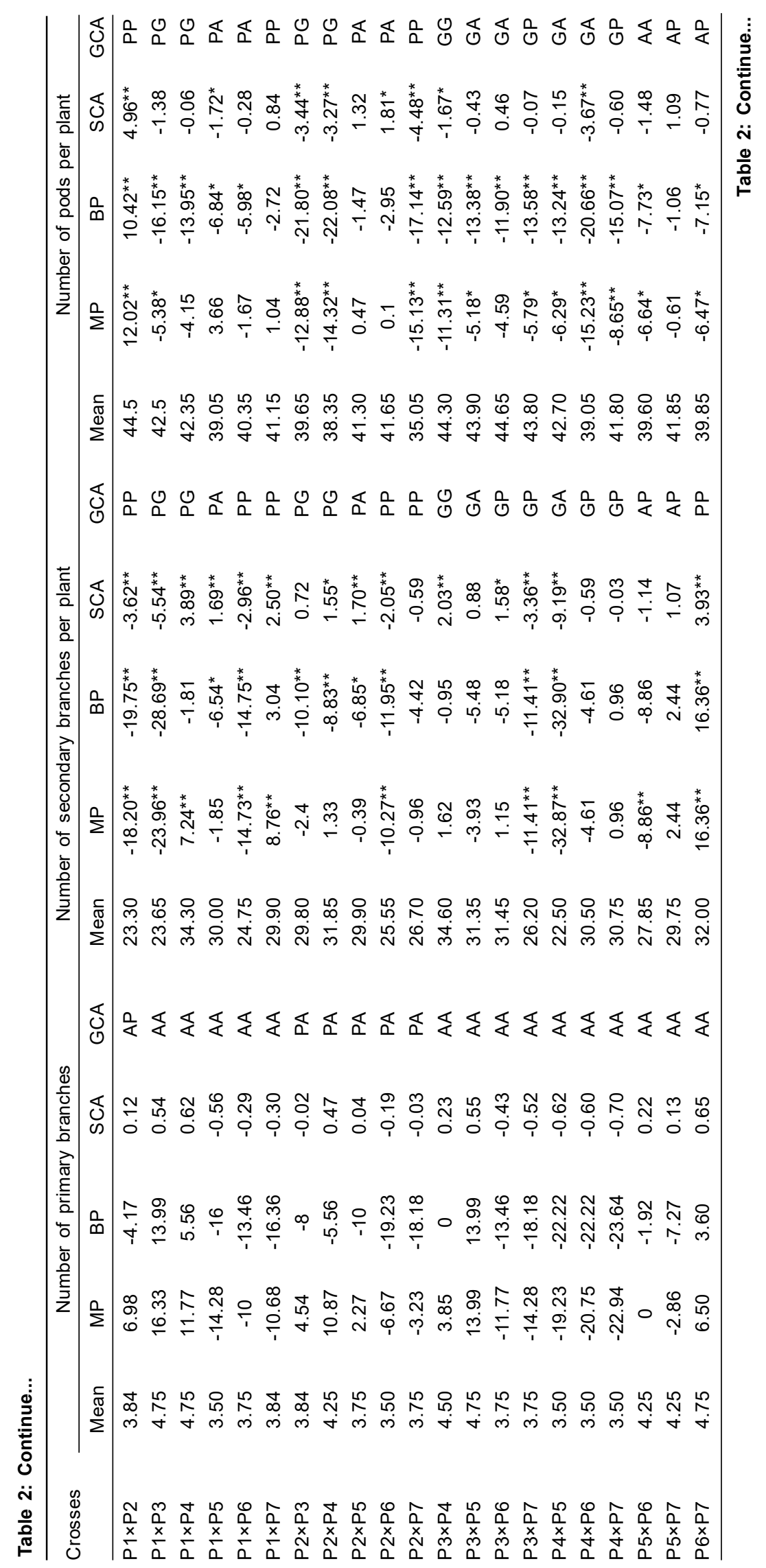




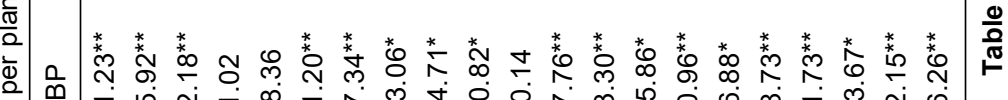

要兽

产

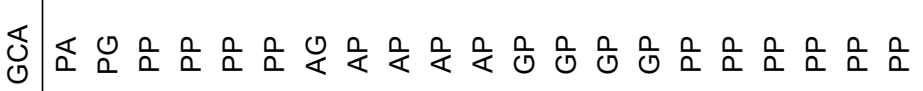

舀

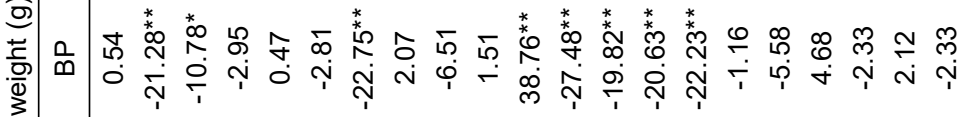

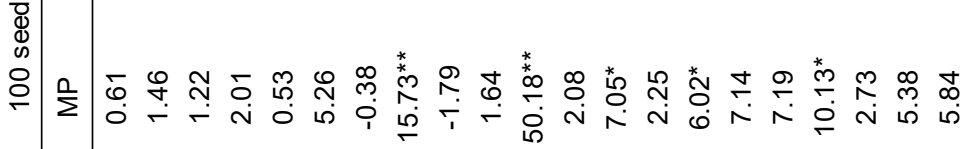

๙

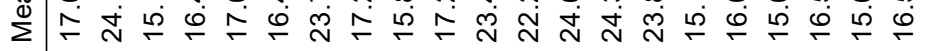

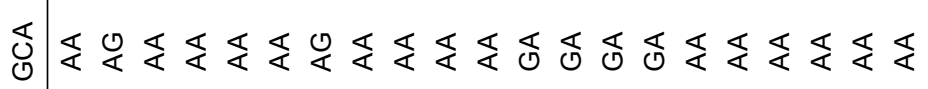

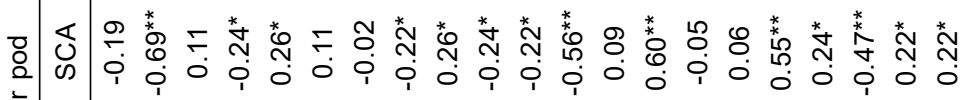

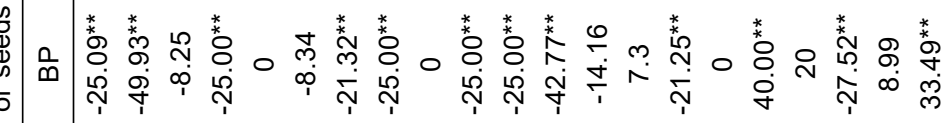

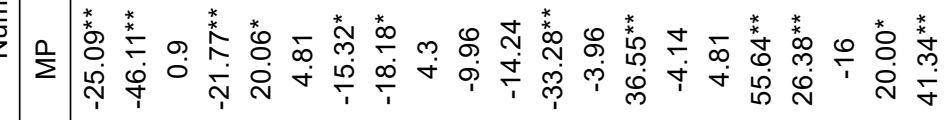

ॠ

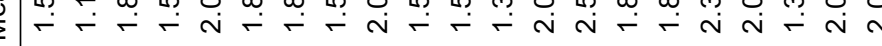

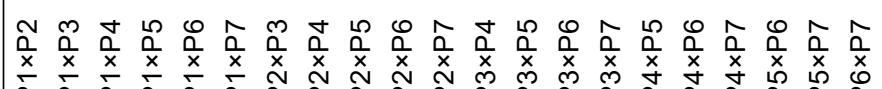




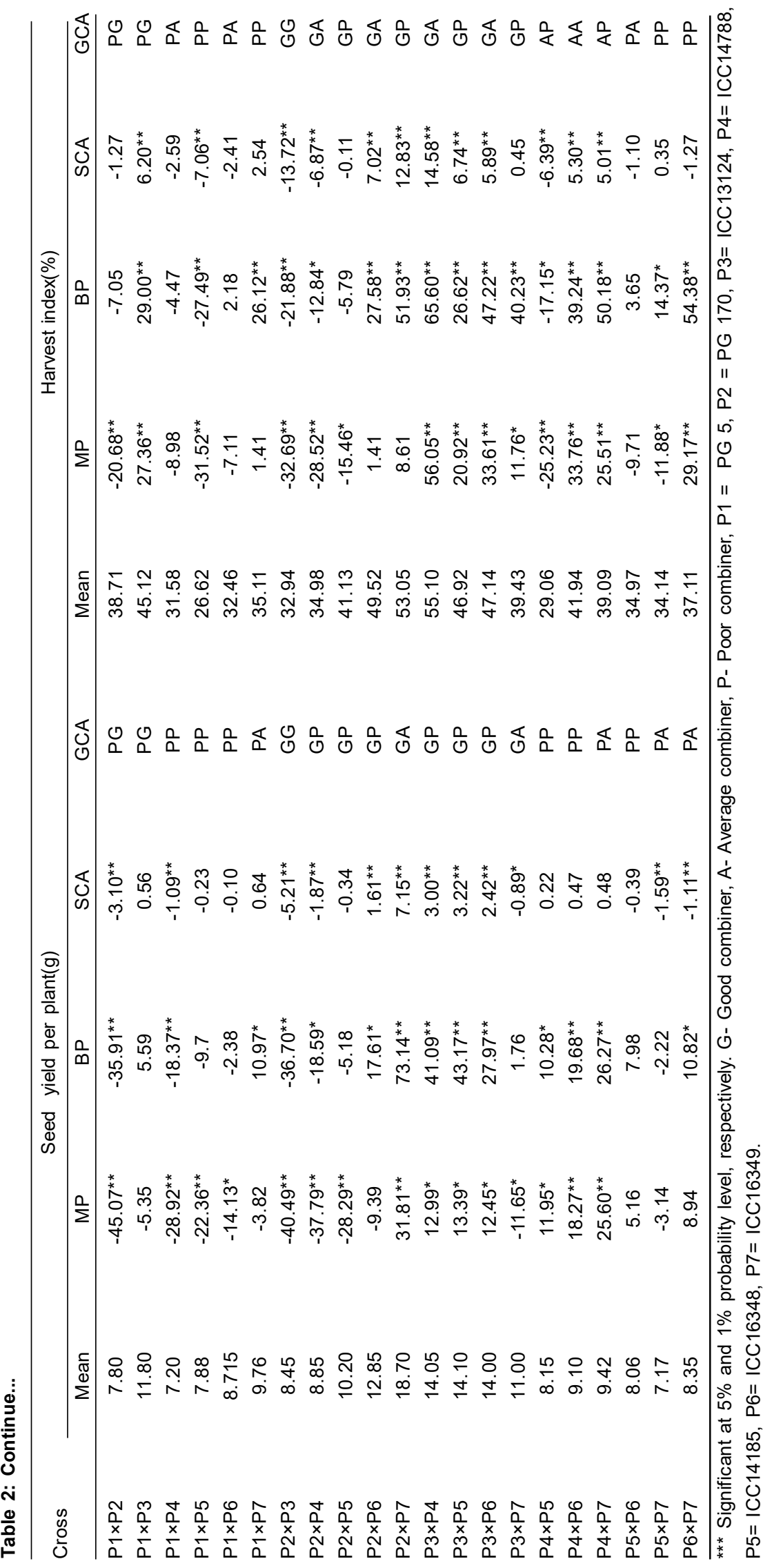


Per se Performance and Heterosis in Relation to Gene Action for Seed Yield and Yield Related Traits in Chickpea

seed weight. The heterotic performance of ICC13124 $\times$ ICC14778 for seed yield per plant was also compared with per se performance and high GCA of ICC13124 and high SCA (Fig 1 and 2). Crosses ICC13124×ICC14815 and ICC $13124 \times$ ICC 16348 exhibited heterotic performance over better and mid parent for seed yield per plant and harvest index. The cross ICC $13124 \times$ ICC 16348 showed heterosis for days to maturity over better parent and for number of seeds per plant over mid parent. However, cross ICC13124 $\times$ ICC14815 showed heterosis over mid parent for 100 seed weight. Higher heterotic expression in the crosses was due to high SCA effect for most of the yield components. On the basis of cross combinations showing highest heterosis in desired direction and best SCA estimates for most of the characters, it is evident that crosses showing high extent of heterosis have high SCA estimates. This indicated that manifestation of heterosis depends upon high estimates of SCA. The studies pertaining to exploitation of heterosis for various yield related traits in chickpea have been conducted by several workers.

In agreement with above findings, Arora and Jeena (2000) reported significant heterosis over mid parent and better parent for all yield and yield contributing traits. Sarod et al. (2000) reported high heterosis for seed yield per plant, pods per plant and 100 seeds weight. The high heterotic effects for secondary branches, biological yield, number of pods/plant, seed yield and plant height observed by Sharif et al. (2001); Bhatnagar et al. (2006) observed for days to flower, plant height, number of primary branches, number of secondary branches, number of pods per plant, 100 seed weight, seed yield per plant and harvest index. Sarode et al. (2016) for seed yield per plant. Babbar (2017) reported significant positive heterosis for days to $50 \%$ flowering, days to pod initiation, number of primary branches, effective pods per plant, number of seeds per plant and seed yield per plant. Bakhsh et al. (2007) observed heterosis over mid parent for primary and secondary branches per plant, 100 seed weight, seed yield per plant and biological yield. Gadekar and Dodiya (2013) reported high significant positive economic heterosis for seed yield per plant, biological yield per plant and number of pods per plant. Bhardwaj et al. (2010) also reported heterosis for number of pods. Parameshwarappa, et al. (2012) reported high positive significant mid parent heterosis for number of pods per plant. High heterosis for seed yield per plant, 100-seed weight over desi parent and for yield per plant alone over kabuli parent in desixkabuli crosses was observed by Gupta et al. 2003.

\section{CONCLUSION}

In the present study, all the characters studied were governed by both additive and non-additive type of gene actions. However, Presence of non additive gene action for most of the yield contributing traits offers enormous possibility of harnessing hybrid vigour in chickpea. However, due to lack of functional male sterility system and cleistogamous nature of flowers, hampers the feasibility of heterosis breeding. To exploit both additive and non-additive gene actions, reciprocal recurrent selection by intermating the most desirable segregants followed by selection may be an alternative breeding strategy for chickpea improvement. However, if a cross combination exhibits high heterosis, sca effect as well as Per se performance having at least one parent as good general combiner for a particular trait, it is expected that such cross combinations would throw some desirable transgressive segregants in later generations subjected to sufficient population grown. For imposing high selection intensity, sibpollination technique can be effectively used. Biparental cross technique may be utilized for accumulation of additive gene effects and breaking undesirable linkage.

\section{ACKNOWLEDGEMENT}

The authors are grateful to International Crops Research Institute for the Semi-Arid Tropics (ICRISAT), Hyderabad, India for providing the chickpea entries of ICC number to GB Pant University of Agriculture and Technology, Pantnagar, Uttarakhand, India.

\section{REFERENCES}

Arora, P.P. and Jeena, A.S. (2000). Heterosis in chickpea (Cicer arietinum L.). Agricultural Science Digest. 20(2): 71-74.

Babbar, A. (2017). Gene action for quantiative traits in chickpea (Cicer arietinum L.). Plant Gene and Trait. 8(2): 8-17. DOI: 10.5376/pgt.2017.08.0002.

Bakhsh, A., Malik, S.R., Iqbal, U. and Arshad, W. (2007). Heterosis and combining ability studies for superior segregants selection in chickpea. Pakistan Journal of Botany. 39(7): 2443-2449. DOI: 10.15740/HAS/ARJCI/7.1/151-154.

Bhardwaj, R., Sandhu, J.S. and singh, I. (2010). Heterosis in relation to combining ability in chickpea (Cicer arietinum L.). Crop Improvement. 37(2): 126-132.

Bhatnagar, S. and Singh, D.K. (2006). Combining ability for seed yield contributing traits in chickpea over generations. Farm Science Journal. 14(1): 57-60.

Fonseca, S. and Patterson, F.L. (1968). Hybrid Vigour in a Seven Parent Diallel Cross in Common Winter Wheat (Triticum aestivum L.). Crop Science. 8(1): 85-88. DOI: https:// doi.org/10.2135/cropsci1968.0011183X000800010025x.

Food and Agriculture Organization. (2019) FAOSTAT Statistical Database of the United Nation Food and Agriculture Organization (FAO) statistical division. Rome.

Gadeker, M.S. and Dodiya, N.S. (2013). Heterosis and combining ability analysis for yield and yield contributing traits in chickpea (Cicer arietinum L.). Legume Research. 36(5): 373-379.

Gupta, S.K., Singh, S. and Kaur, A. 2003. Heterosis for seed yield and its component traits in desi and desi $x$ kabuli crosses of chickpea (Cicer arietinum L.) Crop Improvement. 30(2): 203-207.

Hayes, H.K., Immer, F.R. and Smith, D.C. (1995). Methods of plant breeding. Mc Graw Hill Book Co. Inc., New York. pp 432. 
Per se Performance and Heterosis in Relation to Gene Action for Seed Yield and Yield Related Traits in Chickpea

Malik, S.R., Bakhsh, A., Asif, M.A., lqbal, U. and lqbal, S.M. (2010). Assessment of genetic variability and interrelationship among some agronomic traits in chickpea. International Journal of Agriculture and Biology. 12: 81-85.

Panse, V.G. and Sukhatme, P.V. (1969). Statistical Method for Agriculture Workers. New Delhi, ICAR. pp. 228-232.

Parameshwarappa, S.G., Salimath, P.M., Upadhyaya, H.D., Kajjidoni, S.T. and Patil, S.S. (2012). Heterosis in relation to genetic divergence in minicore collections of chickpea (Cicer arietinum L.). Indian Journal of Genetics and Plant Breeding. 72 (3): 303-308.

Sarode, N.D., Deshmukh, R.B., Patil, J.V., Manjare, M.R. and Mhase, L.B. (2000). Heterosis and combining ability in chickpea. Legume Research. 23(3): 206-209.
Sarode, S.B., Nagargoje, G.P. and Patil, D.K. (2016). Heterosis and combining ability analysis in chickpea (Cicer arietinum L.). Advance Research Journal of Crop Improvement. 7(1): 151-154. DOI: 10.15740/HAS/ARJCI/ 7.1/151-154.

Sharif, A., Bakshsh, A., Hqqani, A.M. and Sara, N. (2001). Identification of genetically superior hybrids in chickpea (Cicer arietinum L.). Pakistan Journal of Botany. 33(4): 403-409.

Varshney, R.K., Mohan, S.M., Gaur, P.M., Gangarao, N.V., Pandey, M.K., Bohra, A., Sawargaonkar, S.L. et al. (2013). Achievements and prospects of genomics-assisted breeding in three legume crops of the semi-arid tropics. Biotechnology Advances. 31: 1120-1134. DOI: 10.1016/ j.biotechadv.2013.01.001. 